\title{
Investigating Effective Factors on Iran's Pistachio Exportation
}

\author{
Seyed fathollah Amiri Aghdaie \\ Assistant Professor, Dep. of management, University of Isfahan \\ Isfahan, Iran \\ Tel: 98-311-7932-651Ｅ-mail: Aghdaie@mang.ui.ac.ir
}

\begin{abstract}
The problem of Iran's economic is depending on oil's incomes, therefore to increase non oil exportation like agricultural products is the main goal of country's economic development program.

The goal of this paper is to investigate effective factors in pistachio exportation and mentioned goal will be consider by variable factors such as export's principle, aflatoxin poison, and packaging.

The type of this paper is descriptive-cognition and the related information for this scope have been collected by using library resources such as books, scientific journals, moreover for collecting necessary data in order to confirm or reject research hypotheses a questionnaire designed by researcher have been used. Statistical society for this research includes the pistachio exporter in Kerman city, the method being used has been random sampling. Results of this investigation shows that the principles of exporting, aflatoxin poison and packaging have great influence in exporting Iran's pistachio.
\end{abstract}

Keywords: Pistachio, Principles of export, Packaging, Aflatoxin poison

\section{Introduction}

Agriculture always has a splendid role in non-oil exportations. It can have an effective share in Iran's exports development if it is looked out by correct management.

Iran has had priority in agriculture since many years ago, and pistachio is one of the most important ones. This crop mostly planted in rain-fed areas in drought and sub drought regions, they give high production when they are planted in region with relatively cold winters and long, hot summers. This is because pistachio needs comparatively cold winter temperatures in order to break bud dormancy. The tree is resistant to cold and wind but can not tolerate excessive dampness and high humidity. Pistachio need almost 10 years to start an early fruit period and 20 years to enter full production period, it is a crop subject to alternate bearing phenomena, in the bearing year the production is very good and in the alternative year is limited. Pistachio has a high nutritional value, 100 grams of the edible of a pistachio contains about 600 calories and is $53 \%$ fat, $21 \%$ protein, $18 \%$ carbohydrates, $2.2 \%$ fiber and no cholesterol. A pistachio has also several kinds of vitamins such as B1, B2, C, and E (www.irandriedfruit.com / Iran-pistachio.php).

Pistachio is also very important in economic terms, as a result it is so-called green gold, and it is one of the most important crops of non-oil exportations. It has been seeded for a long time in Iran. In 1990s share of this crop in non-oil exporting of Iran was almost $13.5 \%$, and in agricultural exports was about $40 \%$. But the amount of that in 2006 has the value of 1068.5 Million US dollars which has assigned 29\% of whole non-oil exportation to itself, (Khalilian and Farhadi, 2002).

According to FAO statistical database in 2005, Iran, USA and Syria have the largest pistachio productive area accounting for $66 \%$ of global area devoted to pistachio for Iran and $9 \%$ for USA and $10 \%$ for Syria (Figure,1).

But as seen in figure 2, the first two producers are Iran with $40 \%$ of the global total and the second USA with $27 \%$ of the global total.

Although Iran is the biggest exporter around of the world due to $40 \%$ production of the world's pistachio and having $60.7 \%$ of the whole world's market (Figure,3), still couldn't compete with it's powerful competitors who have advanced technologies and only involved in various challenges such as, lack of producers that can use the modern methods in producing, packaging, exporting and fighting against pistachio plague. Therefore at the moment those who are responsible have to pay special attention to these challenges, and with a correct management, using new equipment in producing and packaging, using scientific methods in marketing, exporting and fighting against aflatoxin try to increase the quality of pistachio in a standard level and raise their Share in world's market. 
Developing and even keeping the share in the world's market can cause to increase the inland production motivation, investing and making more job opportunities in the field of agriculture and pistachio. As a result, according to the position of Iran in the past and current situation, investigating place of the country in production and exportation of pistachio seems to be very essential.

In this article, it has been tried to recognize the effective factors in Iran's pistachio exportation and presenting appropriate solving methods to develop the exportation, by collecting necessary information.

\section{Subjective literature}

Pistachio is a fruit which comes originally from Iran, it has been cultivated through Iran and has the story of 4000 to 5000 years. About 2500 years ago it has been exported to neighbor countries by Hakhamaneshian kingdom (www.Pestico.blogfa.com)

Since two centuries ago, according to statistical data, it has been exported to foreign countries from following cities: Khorassan, Kerman, Ghazvin, and Damghan (Khalilian and Farhadi, 2002)

Iran's pistachio because of having good taste, beautiful color and standard shape, size is the most famous pistachio around of the world and many people like it, Iranian pistachios have different names according to their shapes. The major varieties are. Round pistachio (Fandoghi): These are the primary product for export, Long pistachio (Akbari): These are the most expensive and traditional, Long pistachio (Ahmad aghaee): These are a favorite amongst people in Eastern Asia, Long pistachio (Badami): The shape of its kernel is similar to almond and Jumbo pistachio (Kale ghuchi): This kind is broad with an opened mouth (www.irandriedfruit.com).

\subsection{Export}

The easiest way to enter foreign markets is exportation, either direct or indirect. So to select the export policy depends on the volume of production. Case export policy happen when the company once in a while sells the crop to foreign countries because of exceeded productions, but active exports happen when the producer decides and guarantees export his product to the aim countries.

In, direct export there is an increase of the capital so benefit will also increase because there is no commission for the brokers but the risk of business is so much.

In, indirect export which is one of the easiest way and common method the product which is export will sale by brokers. This method has two advantages, first you don't have to invest a lot, second its risk is lower because the brokers of foreign markets based on formed relationship provide technical knowledge and necessary services, so the seller makes fewer mistakes.

For the time being, there are three different markets for buying Iran's pistachio. The first one that includes powerful markets, are European countries, Japan, and Canada; they do persist on healthiness and its quality. The second one which includes medium markets. They want crop with delicious taste and good shape such as; Arabic countries and the third group, East Asia, wants pistachio with low price. The most of the pistachio exportations presently are belong to Arab countries and East Asia, anyway according to FAO statistical database (figure, 3) Iran is the leading exporter of pistachio and the nearest competitor is USA.

\subsection{Aflatoxin poison}

Aflatoxin for the first time in 1960 discovered in England when more than thousands turkeys and ducks died within a few months, this disease between birds had been propagated with the symptoms of having no appetite, being sleepy, bended neck and loin, and weakness in wings. Simultaneously the same report for ducks, pheasants and trout had been appeared in different places around the world, after this happen researching group decided to separate Asperilous Flavus fungus from feed of the birds, then fed its poison separately to some animals as a experience, afterwards they saw the same symptoms as before, so they named this poison aflatoxin.(Abdolahi, 2005)

In the field of agriculture also aflatoxin is the major problem. Contamination can occur in the field, during harvest, or in storage and processing. Corn, rice, cottonseed, wheat, peanut, soybean, sunflower, spices, almond, pistachio, walnut, coconut and brazil nut are crops which frequently affected by aflatoxin.

There are two types of fungus, A.parasiticus and A.flarus, which have more effect on leaking aflatoxin poison and poisoning the seed of pistachio than other fungus. The first one has more power than second. This can happen when there is a suitable condition for growing and reproducing inside of pistachio or its seed. This inappropriate condition can happen inside of pistachio only if the crop or its seed encounters wet condition or the level of moisture gets higher.

The core of dry pistachio in the normal situation has between 5 to $7.5 \%$ water. Now, if the dry pistachio placed in moist land or water, its core will absorb some moist and distend. The humid pistachios found ability to absorb the pest or gets musty. So, the core of humid pistachio is a suitable place for fungus to grow and reproduce various kind of mould such 
fungus that producing aflatoxin poison, another factor that causing penetration of fungus is the external shell of pistachio which split on tree so the core of pistachio directly attacked by fungus and pests.

As we know this poison is very dangerous and suggest that in human food is only acceptable with no detectable concentration the maximum allowable concentration of aflatoxin set by the united states FDA is 20 parts per billion $(\mathrm{ppb})$, foreign markets usually reject grains with concentrations of 4 to 15

ppb due to the implementation of new European community regulation on aflatoxin.

\subsection{Packaging}

A product's package serves several functions, protecting, facilitating use of, and promoting the product, as well as providing information about the product and it use. The protection function is critical in both transport and storage, protecting a product under a variety of temperatures and moisture conditions and against being crushed or dropped during handling is no small undertaking.

Because of increasing competition among brands, packages have become an extension of the product and a way of identifying and differentiating products that can lead to increased loyalty, therefore several factors must be weighed in making packaging decisions. Shape, color, material and cost can influence on consumer perceptions and are very important.

Competition in pistachio's world market causes pondering for increasing the quality of this crop. In fact one of the most basic and practical solutions to prevent wholesaling in exportation is to strengthen transforming and completing industries in the field of agriculture and exporting pistachio in the appropriate packages which causes to sell pistachio in higher price; besides with motivating producer the production of the crop will increase too. Nowadays one of the most modern methods of packaging is in vacuum condition.

By using vacuum method the quality of pistachio doesn't change for a long time. This method, which is based on scientific ways, can protect the product against damages that made by hot or cold weather, and even direct sun shine for about two years and also keeps its quality as well as quality of packaging time.

\section{Background of research}

There have been several Studies about agriculture products especially pistachio.

Chambers and just(1981) analyze the effect of exchange rate fluctuations on America's agriculture the results of this analyze shows that the export and price of agricultural product is effected by exchange rate.

Nuri and Kuhpayi (2001), have analyzed about approximation functions of demand and supply of pistachio export. The results of this study shows that the demand extensile of pistachio export than rate of foreign exchange bourse is -0.389 which means the changes of foreign exchange rate has negative effect on the income earned by pistachio's export.

Sharzeyi and Ghanbari (2005), analyze the factors effect on pistachio demand and supply. The results of this analyze show that the demand and cost variables have positive and meaningful effect on supply and demand of pistachio.

\section{Methodology}

The type of this paper is descriptive-cognition and the related information for this scope have been collected by using library resources such as books, scientific journals ,moreover for collecting necessary data in order to confirm or reject research hypotheses, a questionnaire designed by the researcher is used. This mentioned questionnaire has five selective choices and their answers are varied between very less and very more. Furthermore the scope of this research from the view point of subject is investigating effective factors on Iran's pistachio exportation. The time that this research has been done is February 2009. Statistical society of the research includes 30 persons from pistachio exporter in Kerman city and random sampling method was used in this study.

Independent variables in this research include the principles of export, Aflatoxin poison, packaging and dependent variable of this research is the amount of pistachio being exported. In this research for summarizing extractive data to confirm or reject the hypotheses of research used SPSS software and presumption statistics methods (like $\mathrm{T}$ as single sample) have been used, which. T refers to statistic data, in case that Sig (meaningful level) is less than 0.05 hypothesis $\mathrm{H} 0$ will be rejected and hypothesis $\mathrm{H} 1$ will be accepted as well as df indicates free degree.

$\mathrm{H} 0: \mu \leq 0.05$

H1: $\mu \geq 0.05$

\section{Data analysis}

In this section by using given statistical methods, and collecting data and extractive results from questionnaires the research hypotheses have been tested. 


\subsection{First hypothesis}

Familiarity with principle of export is effective on the amount of pistachio's export.

H0: Familiarity with principle of export is not effective on the amount of pistachio's export.

H1: Familiarity with principle of export is effective on the amount of pistachio's export.

As the significant level of (0.0005) is less than (0.05), so the H0 hypothesis will be rejected and H1 hypothesis will be accepted. Therefore familiarity with principle of export is effective on the amount of pistachio's export (table1).

\subsection{Second hypothesis}

Familiarity with Aflatoxin poison is effective on the amount of pistachio's export.

H0: Familiarity with Aflatoxin poison is not effective on the amount of pistachio's export.

H1: Familiarity with Aflatoxin poison is effective on the amount of pistachio's export.

As the significant level of (0.003) is less than (0.05), so the H0 hypothesis will be rejected and H1 hypothesis will be accepted. Therefore familiarity with aflatoxin poison is effective on the amount of pistachio's export (table2).

\subsection{Third hypothesis}

Packaging is effective on the amount of pistachio's export.

H0: Packaging is not effective on the amount of pistachio's export

H1: Packaging is effective on the amount of pistachio's export

As the significant level of (0.0003) is less than (0.05), so the H0 hypothesis will be rejected and H1 hypothesis will be accepted. Therefore packaging is effective on the amount of pistachio's export (table3).

\section{Conclusion and Suggestions}

Pistachio as the second product has an important and strategic place among Iran's non oil export and Iran has been always the most important producer and exporter of pistachio in the world and it allocate a big part of global market place, but during the recent years seems Iran's share has decreased a lot therefore it is an important factor to deliberate about effective elements and challenges on pistachio's export, such as using traditional method instead of scientific and standard ways for exporting, using unsuitable packaging, deficiency of good advertising and marketing in aim countries, having no knowledge regarding Pistachio's plagues especially aflatoxin poison which was the cause for reduction of Iran's pistachio share in world's market.

Working about pistachio shows that today's world and the people of that don't accept traditional method in marketing and exporting , people today are looking after attractive advertisement which be so effective and remain in their mine for long time, create new idea and give them more information regarding products. They are also after beautiful and suitable package, in fact many times we can see customer buy the goods just because of its beautiful package and because of this reason we can see the product that they use already long time ago still care of its package in their houses, therefore how can expect the people of the world buy a product with low package and no effective advertisement.

In exportation case also seems the exporter still use the old method instead of scientific ways because they have no knowledge about that , their mine is only to sale and they don't know which way is the best and how can develop their foreign market.

Above those problems that I mention is aflatoxin poison, this disease is not only the problem of Iran, in all of the world tree of pistachio suffer because of that but results of this investigation shows in Iran majority of pistachio producer don't know about this pest and some times even didn't heard its name while as we told aflatoxin poison is the most important cause of reduction of their pistachio share in world's markets.

There fore having a good, correct and proper programming for supervisors, training and educating the producer, exporter and making them familiar with modern and update knowledge, Combat with pests and decrease aflatoxin in pistachio, having effective advertisement in new markets and using suitable package are the factors that can help us to develop the export of Iran's pistachio and find new markets too.

\section{References}

Al-Shareef, Mohammad. (2007). Comparative advantages of pistachio, national agricultural policy center, working paper no. 30 .

Abdolahi, M. (2005). The role of Aflatoxin in the stability of pistachio market, 5th International conference of Asian society of agricultural economics, Zahedan, Iran.

Blomstermo, Anders and Deosharma, D. (2006). Choice of foreign market entry mode in service firms. International marketing review, Vol. 23, numbers 2 and 3, pp. 211-224. 
Carl, Mc Daniel and Lamb Jr, Charles W. and Hair Jr, Joseph f. (2007). Marketing essentials, fifth edition, Thomson south-western, USA.

Chambers, R and R.E. Just. (1981). Effects of exchange rate changes on U.S. agriculture; a dynamic analysis. American journal of agricultural economics, 63, 32-46.

FAO. (2004). Statistical database, food and agriculture organization of the UN, Rome.

FAO. (2003). Faostat information bank, food and agriculture organization of the UN, Rome.

FAO. (2005). Statistical database, food and agriculture organization of the UN, Rome.

Iranian journal of agriculture and industry. (2004), Numbers 60 and 65.

John W. Mullins and Orvillec, Walker Jr and Happer W, Boyd Jr. (2008). Marketing management a strategic decision-marketing approach, sixth edition, McGraw-Hill, USA.

Http: //www.Pistachio.blogfa.com

Http: //www.Sid.ir

Http: //www.Iran food news.com

Http: //www.Pistachio.research.persianblog.ir

Http: //www.Plant.parsiblog.ir

Http: //www.Irandriedfruit.com/Iran pistachio.php

Http: //www.Fao.org

http://www.American cooperation.org.

Khalilian, S and Farhadi, A. (2002). An investigating of effective factors on exporting of agricultural products. Iranian journal of agricultural economic and development, No. 39.

Moghadas, Al, and Shahi, M. (2007). Investigating of effective factors on agricultural production of Iran in global markets. Journal of agriculture, vol. 13, no. 1, pp. 12-13.

Nuri and Kuhpayi. (2001). An analysis of approximation functions of demand and supply of pistachio export. Iranian journal of agricultural economic and development, Vol. 12, No. 39.

Santos, Paulino. (2002). Trade liberalization and export performance in selected developing countries. Journal of development studies.

Salimifar, M, and Mirzaie. (2002). Comparative advantage of Iran in pistachio's production and export. Iranian journal of agricultural economic and development, Vol. 10, No. 38.

Sherzeyi and Ghanbari. (2000). Analyze the factors on pistachio demand and supply, Third conference of Asian society of agricultural economics, Iran.

Shojii, Yao. (1997). Comparative advantage and crop divercification: Policy analysis matrix for Thai agriculture, J. agri. econ.

USDS. (2004). Data on pistachio exports during 1999-2003, Department of commerce, USA.

Vernon R. Stauble. (2000). Marketing strategy a global perspective, the Dryden press, USA.

Warman, M, and Kennedy, T.L. (1998). Agricultural marketing cooperatives.

Table 1. Familiarity with principle of export is effective on the amount of pistachio's export

\begin{tabular}{|c|c|c|c|}
\hline $\mathrm{t}$ & Average & Df(degree of freedom) & Sig \\
\hline 12.536 & 3.7375 & 29 & 0.0005 \\
\hline
\end{tabular}

\section{Hypothesis test in the error level of 0.05 (reliability level of 0.95 )}

Table 2. Familiarity with Aflatoxin poison is effective on the amount of pistachio's export.

\begin{tabular}{|c|c|c|c|}
\hline $\mathrm{t}$ & Average & Df(degree of freedom) & Sig \\
\hline 3.229 & 3.2933 & 29 & 0.003 \\
\hline
\end{tabular}

Hypotheses test in the error level of 0.05 (reliability level of 0.95 ) 
Table 3. Packaging is effective on the amount of pistachio's export

\begin{tabular}{|c|c|c|c|}
\hline $\mathrm{t}$ & Average & Df(degree of freedom) & Sig \\
\hline 14.538 & 3.9667 & 29 & 0.0003 \\
\hline
\end{tabular}

Hypothesis test in the error level of 0.05 (reliability level of 0.95)

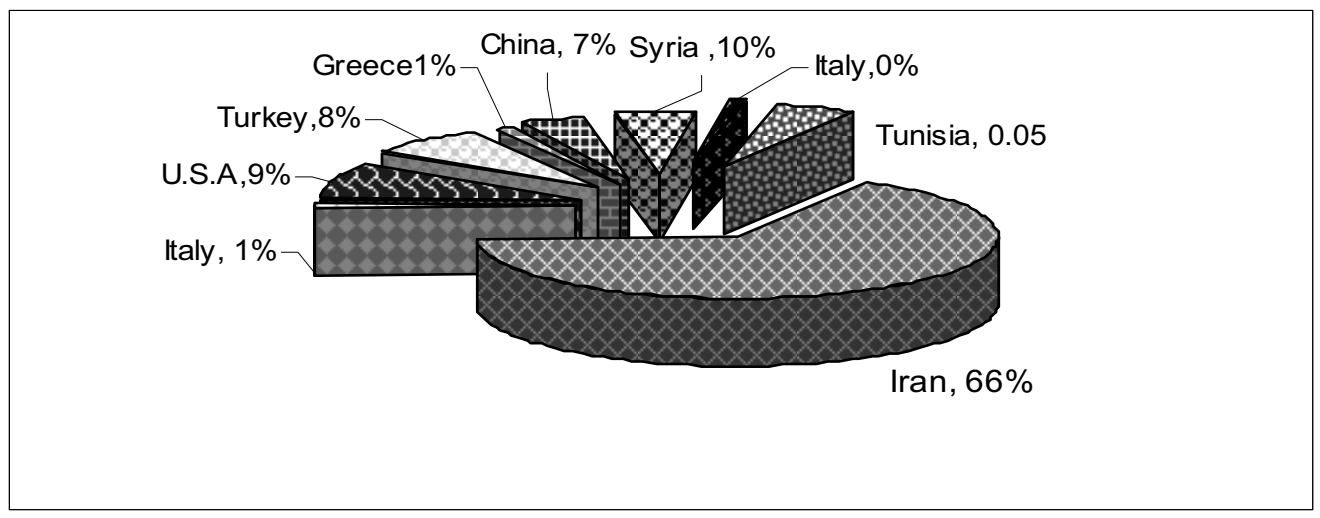

Figure 1. Global pistachio productive area, 2005

Source: Elaborated from fao statistical database

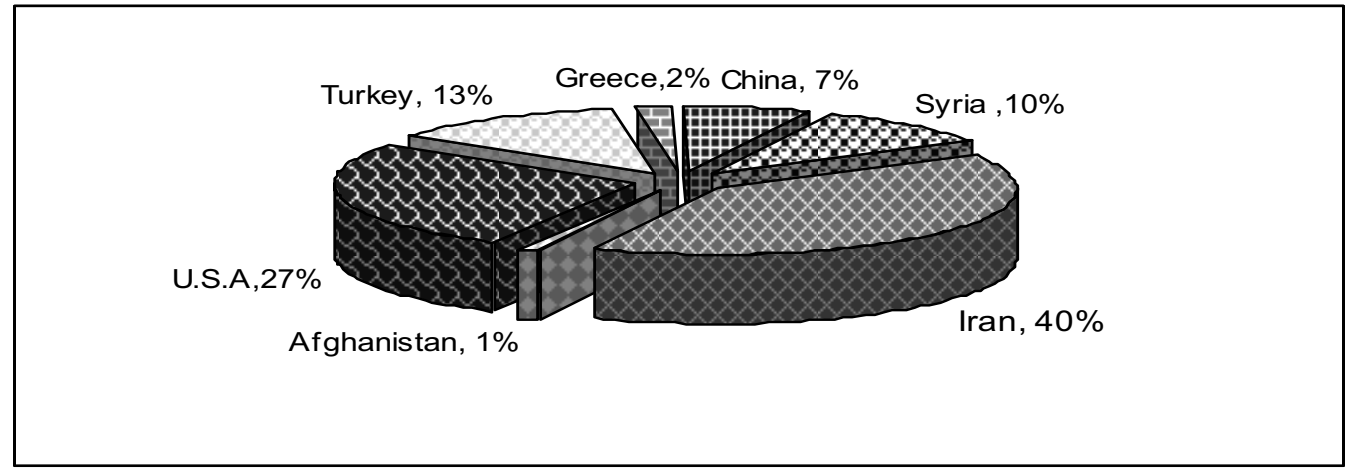

Figure 2. Pistachio production in the world, 2005

Source: Elaborated from FAO statistical database.

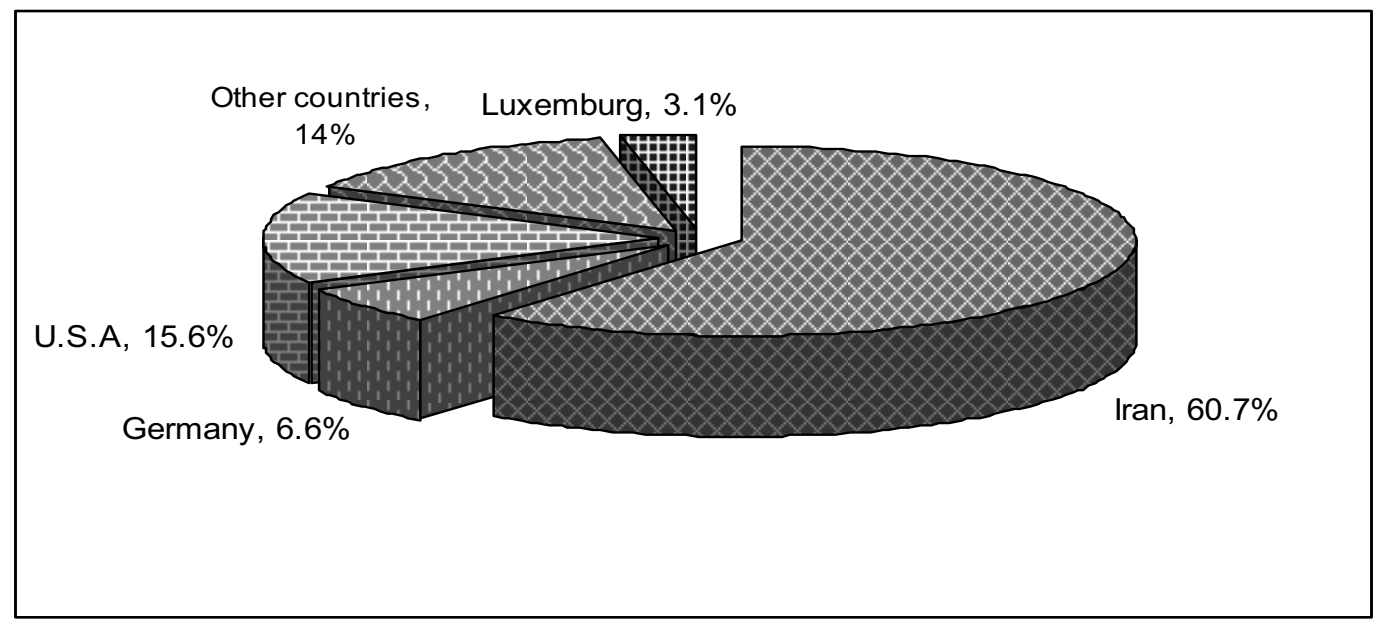

Figure 3. Iran's share in pistachio world's market

Source: Elaborated from FAO statistical database. 